\title{
Resilience of coral calcification to extreme temperature variations in the Kimberley region, northwest Australia
}

\author{
S. S. Dandan ${ }^{1,2,3}$ (1) J. L. Falter ${ }^{1,2,3} \cdot$ R. J. Lowe $\mathrm{L}^{1,2,3} \cdot$ M. T. McCulloch ${ }^{1,2,3}$
}

Received: 15 January 2015/ Accepted: 31 July 2015/Published online: 9 August 2015

(c) The Author(s) 2015. This article is published with open access at Springerlink.com

\begin{abstract}
We report seasonal changes in coral calcification within the highly dynamic intertidal and subtidal zones of Cygnet Bay $\left(16.5^{\circ} \mathrm{S}, 123.0^{\circ} \mathrm{E}\right)$ in the Kimberley region of northwest Australia, where the tidal range can reach nearly $8 \mathrm{~m}$ and the temperature of nearshore waters ranges seasonally by $\sim 9{ }^{\circ} \mathrm{C}$ from a minimum monthly mean of $\sim 22{ }^{\circ} \mathrm{C}$ to a maximum of over $31^{\circ} \mathrm{C}$. Corals growing within the more isolated intertidal sites experienced maximum temperatures of up to $\sim 35{ }^{\circ} \mathrm{C}$ during spring low tides in addition to being routinely subjected to high levels of irradiance $\left(>1500 \mu \mathrm{mol} \mathrm{m}{ }^{-2} \mathrm{~s}^{-1}\right)$ under near stagnant conditions. Mixed model analysis revealed a significant effect of tidal exposure on the growth of Acropora aspera, Dipsastraea favus, and Trachyphyllia geoffroyi $(p \leq 0.04)$, as well as a significant effect of season on A. aspera and $T$. geoffroyi ( $p \leq 0.01$, no effect on $D$. favus); however, the growth of both $D$. favus and $T$. geoffroyi appeared to be better suited to the warm summer conditions of the intertidal compared to A. aspera. Through an additional
\end{abstract}

Communicated by Biology Editor Dr. Anastazia Banaszak

Electronic supplementary material The online version of this article (doi:10.1007/s00338-015-1335-6) contains supplementary material, which is available to authorized users.

S. S. Dandan

ssdandan@internode.on.net

1 ARC Centre of Excellence in Coral Reef Studies, The University of Western Australia, Crawley, WA 6009, Australia

2 The UWA Oceans Institute and School of Earth and Environment, The University of Western Australia, 35 Stirling Highway, Crawley, WA 6009, Australia

3 The Western Australian Marine Science Institution, Perth, WA, Australia comparative study, we found that Acropora from Cygnet Bay calcified at a rate $69 \%$ faster than a species from the same genus living in a backreef environment of a more typical tropical reef located $1200 \mathrm{~km}$ southwest of Cygnet Bay $\left(0.59 \pm 0.02\right.$ vs. $0.34 \pm 0.02 \mathrm{~g} \mathrm{~cm}^{-2} \mathrm{yr}^{-1}$ for $A$. muricata from Coral Bay, Ningaloo Reef; $p<0.001$, $d f=28.9$ ). The opposite behaviour was found for $D$. favus from the same environments, with colonies from Cygnet Bay calcifying at rates that were $33 \%$ slower than the same species from Ningaloo Reef $(0.29 \pm 0.02$ vs. $\left.0.44 \pm 0.03 \mathrm{~g} \mathrm{~cm}^{-2} \mathrm{yr}^{-1}, \quad p<0.001, \quad d f=37.9\right)$. Our findings suggest that adaption and/or acclimatization of coral to the more thermally extreme environments at Cygnet Bay is strongly taxon dependent.

Keywords Coral - Resilience - Extreme temperatures . Thermal stress $\cdot$ Calcification rates $\cdot$ Macro tides

\section{Introduction}

Rising ocean temperatures accompanied by the increased frequency and severity of marine heat waves are testing the physiological ability of coral to withstand extreme thermal stress (Hoegh-Guldberg 1999; Hoegh-Guldberg et al. 2007; Donner et al. 2009; Frieler et al. 2012). Mass bleaching following regional warming events in the Caribbean, Red Sea, and recently in Western Australia, has provided recent evidence of these limits being repeatedly exceeded (e.g., Moore et al. 2012; Furby et al. 2013). Key factors influencing the thermal tolerance of corals are the range and variability in water temperatures to which they are exposed, acting in synergy with specific changes in coral genotype and phenotype, such as the increased production of heat shock proteins and superoxide scavenging as well 
as hosting symbionts with more thermally tolerant genotypes (Baker et al. 2004; Howells et al. 2011; Stat and Gates 2011; Palumbi et al. 2014). Such environmentally dependent resilience is particularly evident in the persistent growth and survival of reef-building coral in extreme environments where temperatures frequently exceed more than $30{ }^{\circ} \mathrm{C}$ (Smith et al. 2007; Oliver and Palumbi 2011; Riegl et al. 2011).

Most of what we currently know about the ecology and physiology of corals living in more thermally extreme reef environments has largely come from three regions: the Persian Gulf, Ofu Island in American Samoa, and the Red Sea. Corals living in the Persian Gulf experience some of the largest seasonal temperature ranges; from winter minima of $11.4-16{ }^{\circ} \mathrm{C}$ to summer maxima of $31-36{ }^{\circ} \mathrm{C}$ (Sheppard et al. 2010) yet support reasonable levels of coral cover $(\sim 20 \%)$, albeit with limited diversity relative to other reef systems (Bauman et al. 2011). Corals in the backreef and shallow pools bounding the island of Ofu in American Samoa can occasionally experience daily fluctuations up to $\sim 6{ }^{\circ} \mathrm{C}$, with a $4{ }^{\circ} \mathrm{C}$ seasonal variation superimposed on that, while the average daily temperature of Ofu lagoon is $\sim 29^{\circ} \mathrm{C}$ in summer (Piniak and Brown 2009; Oliver and Palumbi 2011). Nonetheless, these reef communities also support reasonable levels of coral cover (25-26\%) and high diversity (Craig et al. 2001) with reasonably robust rates of coral growth $\left(\sim 1.4 \mathrm{~g} \mathrm{~cm}^{2} \mathrm{yr}^{-1}\right.$; Smith et al. 2007). In the Red Sea, Pineda et al. (2013) found higher rates of bleaching in corals living on the more exposed, seaward sides of nearshore reefs than corals living on the more protected, shoreward sides, despite much higher temperature elevations and variations within the more protected sites, thus suggesting some form of environmentally dependent resilience related to prior history of thermal variability and exposure (Carilli et al. 2012; Castillo et al. 2012).

Although it is clear that corals can survive in thermally extreme reef environments, it is still unclear how fast many of these corals are actually growing through active biomineralization or calcification. Currently, there are few data on the in situ rates at which corals living in these environments calcify, particularly on a quantitatively comparable basis (e.g., $\mathrm{CaCO}_{3}$ amassed per unit bioactive surface area per unit time). As long as bleaching or some other form of sublethal thermal stress is not triggered, then higher temperatures could support higher rates of calcification given the influence of temperature on the rate kinetics of aragonite precipitation (Burton and Walter 1987; McCulloch et al. 2012). Early work showed that rates of coral calcification generally increase with temperature until reaching some optimal rate and then declining substantially as water temperatures approach $\sim 30{ }^{\circ} \mathrm{C}$, likely as a result of increased levels of thermal stress (Jokiel and Coles 1977; Marshall and Clode 2004). Some field studies have demonstrated that rates of calcification in Porites are highly correlated with regional changes in water temperature (Cooper et al. 2012; Lough and Cantin 2014), while others have shown that in situ rates of extension and calcification can decrease at abnormally high temperatures (De'ath et al. 2009; Cantin et al. 2010; D'Olivo et al. 2013). Thus, thresholds for the sublethal effects of thermal stress on growth appear to vary with climatological regime as well as acclimatization or adaptation of local coral communities.

Corals living in the nearshore Kimberley region of Western Australia are exposed to average monthly temperatures of around $22{ }^{\circ} \mathrm{C}$ in July to over $31^{\circ} \mathrm{C}$ in December and exceed $30{ }^{\circ} \mathrm{C}$ on average for around 5 months each year (Richards et al. 2015). They are also subject to diurnal tidal amplitudes of up to $11 \mathrm{~m}$ (Kowalik 2004) that can expose corals to potentially stressful and damaging levels of temperature and light (Anthony et al. 2007). Furthermore, water motion can become stagnant during such low tide (Lowe et al. 2015), decreasing rates of oxygen export and increasing oxidative stress (Lesser and Farrell 2004; Anthony and Kerswell 2007; Mass et al. 2010), as well as increasing the temperature of coral tissue above already elevated ambient levels (Fabricius 2006; Jimenez et al. 2008). Thus, intertidal and nearshore environments along the Kimberley coast provide a challenging thermal environment to which corals have adapted, yet to date we have found no record of extensive coral bleaching on a regional scale along the Kimberley coast. Despite its potential value for understanding coral growth under extreme conditions, this area has received little attention beyond conducting habitat surveys (Rosser and Veron 2011; Wilson and Blake 2011; Richards et al. 2015). Instead, greater focus has been placed on the offshore reefs to the north of the Kimberley coast, such as Scott Reef, due to their potential as natural gas reserves (e.g., Cooper et al. 2010; Gilmour et al. 2013).

Numerous studies have already examined the community structure (Craig et al. 2001; Riegl et al. 2001), physiology (Smith et al. 2007; Putnam and Edmunds 2011), and/or genomics (Oliver and Palumbi 2009; Barshis et al. 2013) of corals living in various high-temperature environments. In the present study, we measured seasonal changes in the calcification rates of three coral species: the branching Acropora aspera, the flabello-meandroid Trachyphyllia geoffroyi, and the massive Dipsastraea favus, in both subtidal and intertidal environments over a 17-month period (April 2011 through September 2012; Fig. 2), where diurnal ranges in mean hourly temperature reached up to $\sim 7{ }^{\circ} \mathrm{C}$. We show that the corals within these high and variable temperature environments grow and calcify at rates comparable to similar species of hermatypic 
corals living in the more moderate temperature environments of Coral Bay in Ningaloo Reef, Western Australia.

\section{Materials and methods}

\section{Field sites}

The Kimberley is a region in northwest Australia spanning latitudes $\sim 15^{\circ}-20^{\circ}$ and longitudes $\sim 121^{\circ}-129^{\circ}$, and containing over $20,000 \mathrm{~km}$ of coastline. Our field site was at Shenton Bluff, a coastal protrusion located on the north end of Cygnet Bay, situated on the northwest coast of King Sound, where the spring tidal range can reaches over $8 \mathrm{~m}$ $\left(16^{\circ} 48^{\prime} \mathrm{S}, 123^{\circ} 04^{\prime} \mathrm{E}\right.$; Fig. 1). Natural barriers situated throughout the semi-emergent portion of this coastal protrusion create a network of loosely interconnected tidal pools whose depth and period of isolation during low tide vary according to changes in local elevation as well as the tortuosity of the pathways by which water can enter and exit each pool during the incoming and outgoing tide. The presence of these natural barriers combined with largescale $(10 \mathrm{~s}-100 \mathrm{~s} \mathrm{~m})$ depressions in the local bathymetry ensures that some water is retained in each pool even when offshore sea levels are several metres lower than the minimum depth of the pool. These types of intertidal environments are commonly found in other shallow coastal environments throughout the Kimberley (Wilson and Blake 2011; Lowe et al. 2015; Richards et al. 2015). We chose three experimental sites subjected to varying degrees of tidal influence so that we could get the broadest range of light and temperature variability: (1) a shallow intertidal pool with a minimum depth during spring low tide of $\leq 0.2 \mathrm{~m}$ which gets completely isolated at low tide (herein referred to as 'isolated'), (2) an intertidal pool with a minimum depth of $\sim 0.5 \mathrm{~m}$ that is only briefly isolated from King Sound at the very peak ebb of low tide (herein referred to as 'intermediate'), and (3) a subtidal site with a minimum depth of $\sim 1 \mathrm{~m}$ that is never tidally isolated or otherwise disconnected from King Sound (herein referred to as 'subtidal'; Fig. 2).

To compare the coral calcification rates measured in the Kimberley with similar genera in a more typical tropical reef environment, a second study site was set up at Coral Bay in the southern part of the Ningaloo Reef Tract $\sim 1200 \mathrm{~km}$ southwest of Cygnet Bay $\left(23^{\circ} 14^{\prime} \mathrm{S}, 113^{\circ} 55^{\prime} \mathrm{E}\right.$; Fig. 3). This site was selected for having seasonal temperature variations closer to the median for most tropical reefs $\left(22-28{ }^{\circ} \mathrm{C}\right.$, mean of $25{ }^{\circ} \mathrm{C}$; Veron 2000 ; Zhang et al. 2013). Seasonal temperature maxima and minima at Ningaloo occur during the autumn and spring (April and September, respectively) lagging seasonal solar maxima and minima by $\sim 3$ months (Falter et al. 2012). Circulation in Coral Bay is predominantly wave-driven while tides are
Fig. 1 Map of a Australia, b Dampier peninsula in the Kimberley region, c Cygnet Bay on the Dampier Peninsula, and d Shenton Bluff with the three study sites

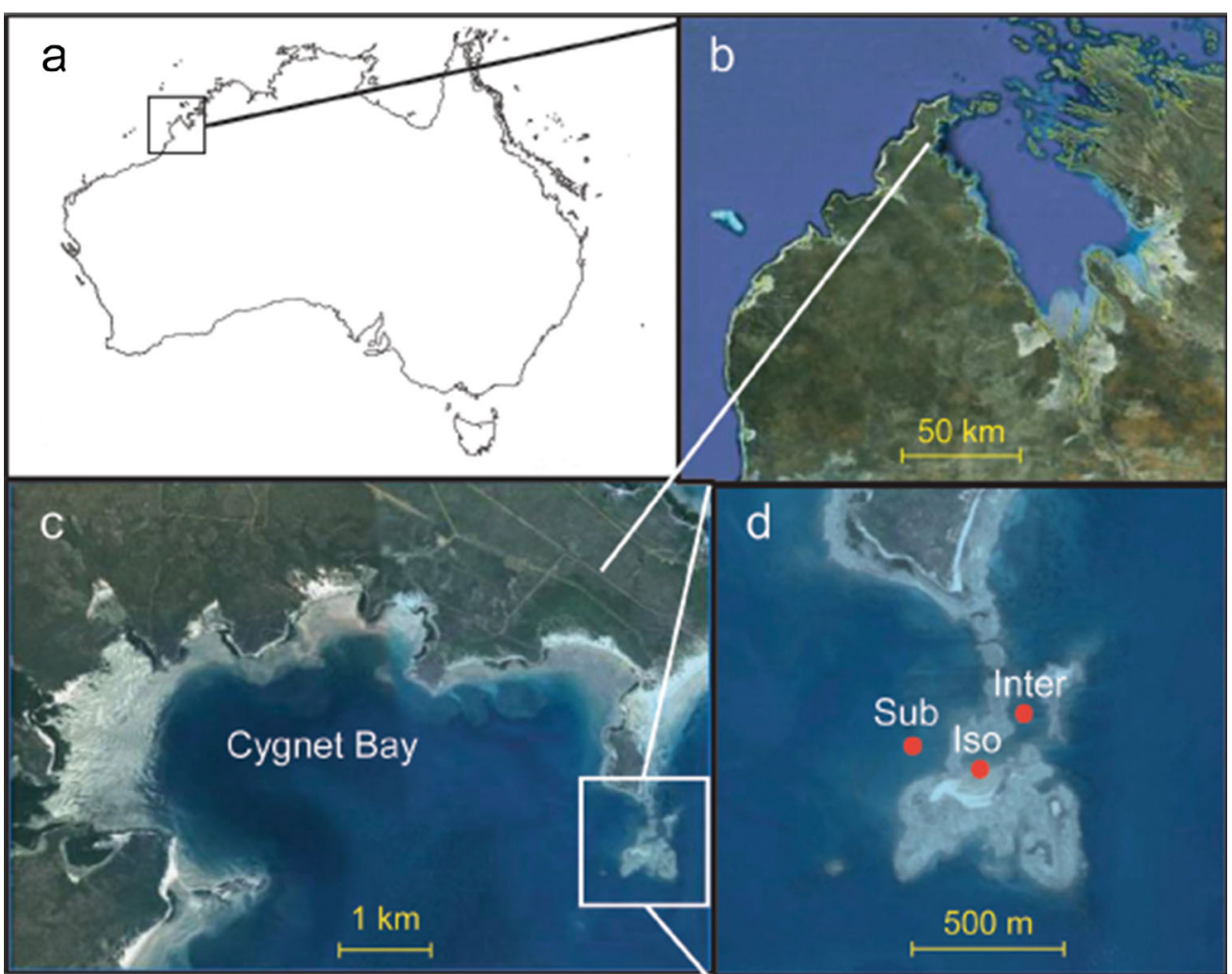



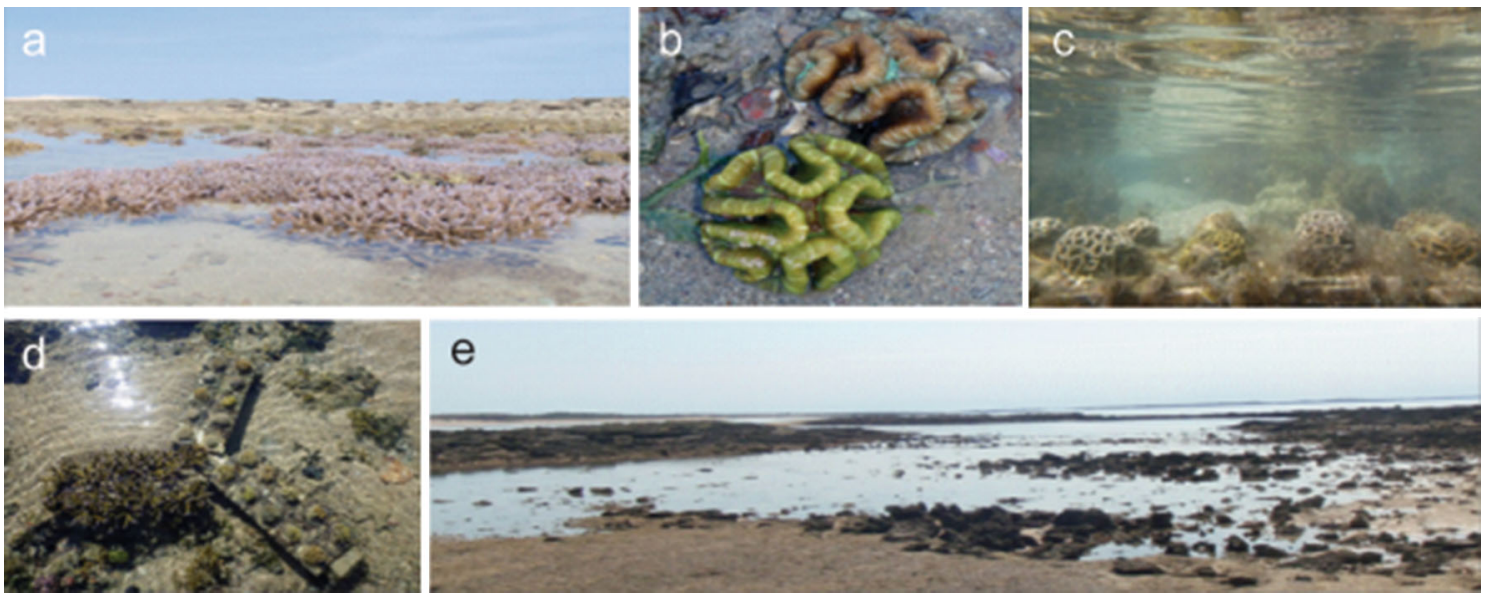

e

Fig. 2 a Colonies of Acropora aspera exposed at low tide in an intertidal site, Cygnet Bay. b Colonies of Trachyphyllia geoffroyi exhibiting two distinct colour morphs. c Side view of Dipsastraea favus mounted on tiles for determination of calcification rates. $\mathbf{d}$ Plan

view of tripod frame in tide pool at the end of experiment with live coral specimens. e Eye-level view of tidal pools formed during a spring low tide

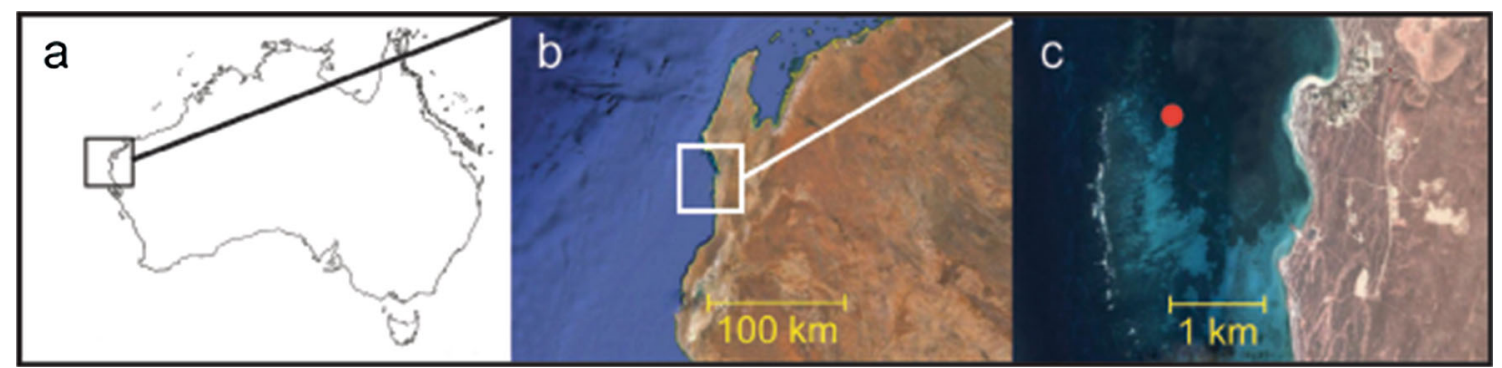

Fig. 3 Map of a Australia, b Coral Bay located south of the North West Cape on Ningaloo Reef, and c location of study site within Coral Bay

semidiurnal and generally do not exceed a range of $0.7 \mathrm{~m}$ (Zhang et al. 2012), thus providing even greater contrast with the Kimberley. For our comparative study, we chose a site on the backreef flat ( $\sim 2.5 \mathrm{~m}$ deep; Fig. 2$)$ that was well flushed by offshore waters to minimize the impact of reef-scale variations in water temperature and chemistry due to the longer residence times in the more landward sections of the lagoon (Zhang et al. 2012, 2013; Falter et al. 2014).

\section{Environmental data}

At Cygnet Bay, we deployed HOBO Pro v2 Water Temperature Data Loggers (U22-001; $\pm 0.2{ }^{\circ} \mathrm{C}$ ) at all three sites and Hobo Water Level Loggers (U20-001-02-Ti; $\pm 5 \%$ ) at the isolated and subtidal sites from March 2012 through the end of August 2012 with the collection of temperature data at the subtidal beginning in September 2010 with the preliminary survey work and ending in August 2012. Downwelling planar PAR irradiance at the benthos was measured continuously (sampling every $10 \mathrm{~min}$ ) at each site, during each field survey, for approximately 1 week using an Odyssey light sensor (Photosynthetic Irradiance Recording System; $\pm 6 \%$ ). Each of these sensors had previously been calibrated under water against a factory-calibrated LiCor 192SA PAR sensor. Downwelling light along with salinity $( \pm 0.002)$ and temperature $( \pm 0.002)$ was also measured using an RBR XR-420CTPAR (RBR Ltd., Ontario, Canada) equipped with a LiCor 192SA sensor at the intermediate site.

Total alkalinity (TA; $\pm 5 \mu \mathrm{eq} \mathrm{L}^{-1}$ ) was measured on filtered water samples $(0.7 \mu \mathrm{m})$ collected from all sites, using an approach based on the spectrophotometric method of Yao and Byrne (1998), and calibrated against Certified Reference Materials provided by Andrew Dickson at the Scripps Institute of Oceanography (batch \#105). Seawater $\mathrm{pH}$ was measured on the total scale $( \pm 0.03)$ using a Schott Handylab $12 \mathrm{pH}$ metre equipped with a Blueline $24 \mathrm{pH}$ electrode calibrated at UWA against seawater $\mathrm{pH}$ standards also provided by Andrew Dickson (batch \#7). Dissolved inorganic carbon (DIC), the partial pressure of dissolved carbon dioxide $\left(p \mathrm{CO}_{2}\right)$, and aragonite saturation state $\left(\Omega_{\mathrm{ar}}\right)$ 
were calculated from measured $\mathrm{pH}$, TA, temperature, and salinity using the CO2SYS program (Lewis and Wallace 1998).

\section{Coral calcification}

We chose three genera of corals representing a variety of growth forms and taxa that were commonly abundant around Cygnet Bay: the branching coral A. aspera (Wallace 1999; Veron 2000), the flabello-meandroid coral $T$. geoffroyi (Veron 2000), and the massive coral D. favus (Veron 2000; Budd et al. 2012). To compare the calcification of Cygnet Bay corals with those growing in more typical reef environments, we measured calcification rates in the following corals at Coral Bay: the branching coral Acropora muricata (Wallace 1999), which has a similar skeletal density to $A$. aspera (0.92 vs. $1.09 \mathrm{~g} \mathrm{~cm}^{-3}$, Bucher et al. 1998), the massive coral D. favus, and the flabellomeandroid Lobophyllia hemprichii. While we would have preferred to compare the calcification of a flabello-meandroid coral species of the same genera, the primary objective of the current study was to compare the calcification rates of representative corals between different regions, rather than how a particularly cryptic coral species survives at the limits of its habitat range.

Branches of A. aspera (8-17 g), A. muricata (2-11 g), and L. hemprichii (16-65 g) were collected from independent parent colonies to avoid repetitive sampling of the same colony, whereas we collected whole colonies of solitary $T$. geoffroyi of $5-8 \mathrm{~cm}$ in size (13-40 g) and small colonies of $D$. favus, $5-8 \mathrm{~cm}$ in size $(10-60 \mathrm{~g})$. Coral specimens were attached to acrylic tiles using the marine epoxy Z-SPAR and mounted on a tripod at each experimental site (Fig. 2). Following the completion of each individual growth season, the mounted coral specimens were first cleaned of epiphytic growth and then buoyantly weighed ( $\pm 0.01 \mathrm{~g}$; Bak 1973; Jokiel et al. 1978). Total bioactive surface areas were calculated from a priori relationships between total surface area and dry skeletal mass for each species determined from separately collected coral colonies. The total surface areas of T. geoffroyi, L. hemprichii, and D. favus colonies were measured using the aluminium foil technique (Marsh 1970), while the total surface areas of the branching Acropora spp. were estimated from the height and diameter of each branch assuming a roughly cylindrical geometry (Bak and Meesters 1998; Naumann et al. 2009). We then used the measured changes in buoyant weight and mass-dependent surface areas to calculate the areal rates of net calcification over each growth interval ( $g$ net in $\mathrm{mg} \mathrm{CaCO}_{3} \mathrm{~cm}^{-2} \mathrm{~d}^{-1}$ ). Sampling times were chosen, so that growth intervals spanned either winter (March/April to September) or summer (September to March/April). Over the course of our study, we measured changes in buoyant weight in April 2011, September 2011, March 2012, and September 2012. Thus, we were able to measure seasonal changes in rates of coral calcification over two winters and one summer. To calculate annual rates of calcification for each coral taxon from our seasonal measurements, we first averaged both winter measurements and then averaged this resulting value with the summer measurement.

\section{Statistical analysis}

Two separate mixed effect models examining the influence of two independent factors on calcification rate were run for each of the three genera studied (either Acropora, Dipsastraea, or Trachyphyllia) with one common factor being each individual season (winter, summer, then winter). The second factor we considered was location based on one of either two separate spatial scales: local (intertidal vs. subtidal at Cygnet Bay only) or regional (Cygnet Bay vs. Coral Bay, subtidal habitats only). Given that all independent factors considered were categorical and therefore dimensionless, all coefficients generated by the mixed effect model were thus in units of $\mathrm{g} \mathrm{cm}^{-2} \mathrm{yr}^{-1}$. We did not perform a cross-regional comparison of calcification rates between $T$. geoffroyi at Cygnet Bay and $L$. hemprichii at Coral Bay, given that they were too taxonomically different from one another. Nonetheless, we still report calcification rates for L. hemprichii in this paper for reference in future work. All statistical analyses were performed using the software SPSS v22 (IBM, Armonk, USA).

\section{Results}

\section{Environmental conditions}

We collected our measurements during spring tides when the duration of intertidal isolation or 'slack water period' was $\sim 2 \mathrm{~h}$ for the intermediate pool and $\sim 4 \mathrm{~h}$ for the isolated pool. Daily average water temperatures at the subtidal site at Cygnet Bay tidal pools ranged from $21.9{ }^{\circ} \mathrm{C}$ in the peak of winter (June-July) to $31.7{ }^{\circ} \mathrm{C}$ in the peak of summer (December-January) and averaged $>31{ }^{\circ} \mathrm{C}$ for 38 d between December 2011 and January 2012 (Fig. 4). Differences between the mean daily temperatures of each of the Intertidal sites and the subtidal site were not that substantial when averaged over the course of the winter and summer seasons $\left(\sim 0.1{ }^{\circ} \mathrm{C}\right)$. However, diurnal variations in water temperature were far more pronounced at the intermediate and isolated sites than at the subtidal site where maximum solar heating and cooling occurred and particularly during spring low tides. For example, the 

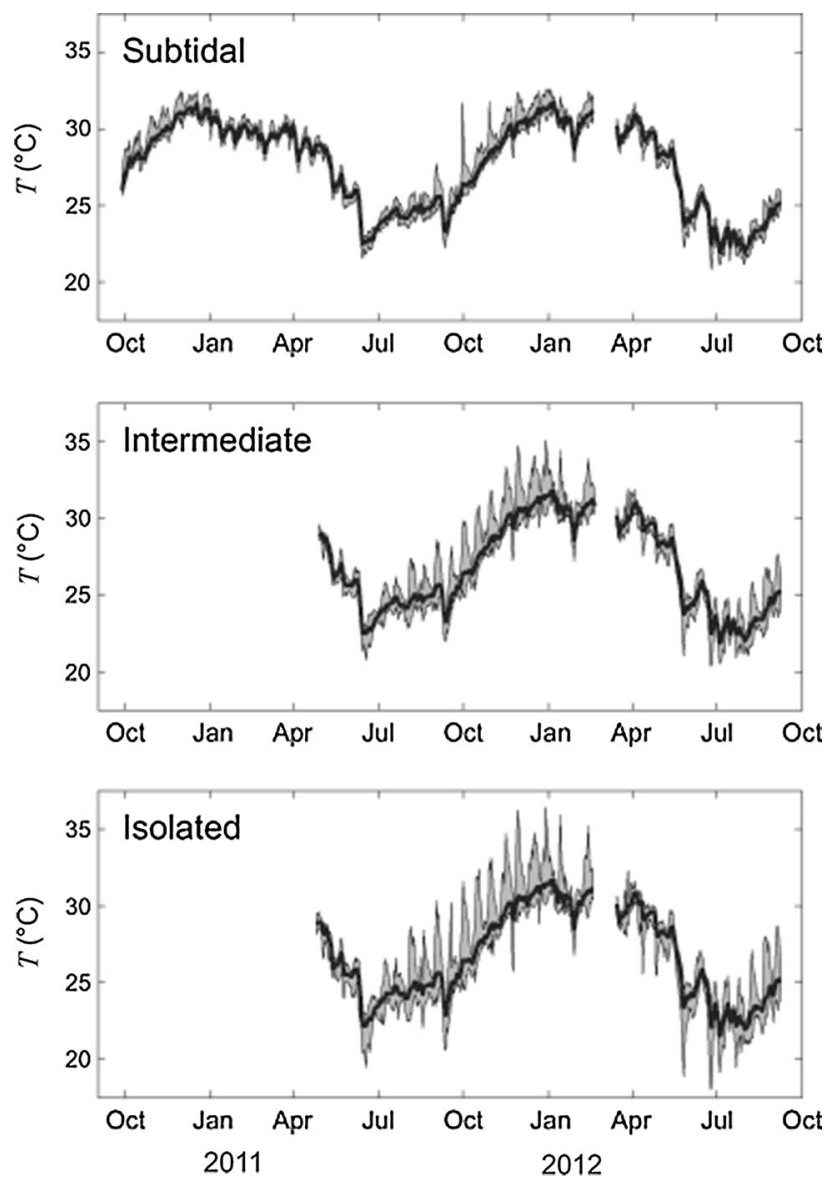

Fig. 4 Water column temperatures recorded at the three Cygnet Bay sites: subtidal, intermediate, and isolated sites from September 2010 through August of 2012. The heavy black line represents daily average temperatures, while the grey regions represent the range between hourly minimum and maximum temperatures for each day. All growth experiments began in April 2011. Note the large tidally driven cycles in temperature of $\sim 4{ }^{\circ} \mathrm{C}$ that are superimposed upon the seasonal cycle resulting in summer maximum temperatures in the isolated pools of up to $35^{\circ} \mathrm{C}$

diurnal range in mean hourly temperatures (maximum minus minimum) exceeded $3{ }^{\circ} \mathrm{C}$ for $41 \%$ of the year at the isolated site, $24 \%$ of the year at the intermediate site, and only $1.6 \%$ of the year at the subtidal site and further reached up to $\sim 7^{\circ} \mathrm{C}$ at the isolated site during summer. The highest hourly temperature recorded throughout the study was $37.3{ }^{\circ} \mathrm{C}$ at the isolated site in December 2011. Thus, during the summer of 2011-2012, daytime temperatures would frequently exceed $33{ }^{\circ} \mathrm{C}$ at the intermediate site (on $19 \mathrm{~d}$ ) and $34{ }^{\circ} \mathrm{C}$ at the isolated site (on $14 \mathrm{~d}$ ). Night-time excursions were generally much smaller than the corresponding daytime elevations, exhibiting only a $1-2{ }^{\circ} \mathrm{C}$ drop in temperature. Salinity ranged between 33.6 and 34.4 for the post-winter field surveys and averaged 34.1 for the post-summer survey (Table 1). Maximum daily light levels at the subtidal and intermediate sites ranged from $\sim 1000$ to $1800 \mu \mathrm{mol} \mathrm{m} \mathrm{m}^{-2} \mathrm{~s}^{-1}$ depending on tidal elevation, water clarity, and cloud cover (Fig. 6); however, maximum daily light levels in the isolated site reached $\sim 2100-2400 \mu \mathrm{mol} \mathrm{m}{ }^{-2} \mathrm{~s}^{-1}$ in March 2012 due to its particularly shallow depth at low tide $(0.2-0.3 \mathrm{~m}$; Fig. 6).

There was substantial within-season variation in water column carbonate chemistry due to our measurements being limited to discrete sampling during daylight hours and at low tide when rates of net production and net calcification are highest and the water column shallowest $(\sim 0.2 \mathrm{~m}$ in the isolated habitat), thus making it difficult to discriminate between the effects of diurnal and seasonal variation in our data (e.g., Manzello et al. 2014). Nonetheless, given that these samples were collected at the same sites, at the same time of day ( $\sim 8: 00-11: 00)$ and during the same phase of tide, we doubt that there was much seasonal bias in TA beyond what would be expected from seasonal changes in salinity $\left(+0.9 \%\right.$ or $+19 \mu \mathrm{eq} \mathrm{kg}^{-1}$ from summer to winter versus $+10 \mu \mathrm{eq} \mathrm{kg}{ }^{-1}$ observed; Table 1). In summer, average daytime $\mathrm{pH}$ ranged from 8.06 in the subtidal to 8.12 in the isolated pool, while in winter it ranged from 8.11 at the subtidal site to 8.17 at the isolated site (Table 1). Although daytime $\mathrm{pH}$ was significantly higher in winter than in summer by $\sim 0.05$ ( $p<0.05$ ), differences of this magnitude are unlikely to have a marked effect on rates of coral calcification given the ability of most coral to biologically elevate $\mathrm{pH}$ at the site of calcification by $\sim 0.5$ units (McCulloch et al. 2012; Venn et al. 2013). Consequently, during the day the partial pressure of dissolved carbon dioxide in the water column $\left(p \mathrm{CO}_{2}\right)$ reached values that were below atmospheric values, and aragonite saturation state $\left(\Omega_{\mathrm{ar}}\right)$ reached values that averaged between 4.0 and 4.25 for the intertidal sites and between 3.5 and 3.9 at the subtidal site (Table 1).

At Coral Bay, water column temperatures at our study site averaged $\sim 23.3{ }^{\circ} \mathrm{C}$ in winter (May through October) and $\sim 25.7{ }^{\circ} \mathrm{C}$ in summer (November through April; Falter et al. 2014; Fig. 5). Unlike the three sites at Cygnet Bay, the diurnal range in mean hourly temperatures (maximum minus minimum) at the Coral Bay site never exceeded $3{ }^{\circ} \mathrm{C}$ during the year-long measurement period. Benthic light levels reached maximum hourly irradiances of around $1100-1200 \mu \mathrm{mol} \mathrm{m} \mathrm{m}^{-2} \mathrm{~s}^{-1}$ in summer and $800-850 \mu \mathrm{mol} \mathrm{m}^{-2} \mathrm{~s}^{-1}$ in winter (data not shown); results were comparable to prior measurements made on shallow reef flats in this region (Falter et al. 2012; Zhang et al. 2012). Salinity at Coral Bay exhibited a negligible difference between season (34.8 in winter and 34.9 summer; Table 1). Total alkalinity at the backreef site in Coral Bay averaged $2286 \mu \mathrm{eq} \mathrm{kg}{ }^{-1}$ in summer and $2222 \mu \mathrm{eq} \mathrm{kg}{ }^{-1}$ in winter, whereas daytime $\mathrm{pH}$ averaged 8.09 in summer and 8.15 in winter. Thus, daytime $p \mathrm{CO}_{2}$ values were lower than 
Table 1 Average water column carbonate chemistry and temperature from discrete measurements made at the study sites in Cygnet Bay and Coral Bay in summer and winter

\begin{tabular}{|c|c|c|c|c|c|c|c|c|}
\hline Site & Season & $\mathrm{T}\left({ }^{\circ} \mathrm{C}\right)$ & $S(-)$ & $\mathrm{pH}(-)$ & $\mathrm{TA}\left(\mu \mathrm{eq} \mathrm{kg}{ }^{-1}\right)$ & DIC $\left(\mu \mathrm{mol} \mathrm{kg}{ }^{-1}\right)$ & $p \mathrm{CO}_{2}(\mu \mathrm{atm})$ & $\Omega_{\mathrm{ar}}(-)$ \\
\hline \multicolumn{9}{|l|}{ Cygnet Bay } \\
\hline Isolated & Summer & 32.0 & 33.7 & 8.12 & 2132 & 1751 & 293 & 4.32 \\
\hline Std. Err. & & \pm 0.7 & \pm 0.2 & \pm 0.02 & \pm 34 & \pm 49 & \pm 27 & \pm 0.16 \\
\hline Isolated & Winter & 25.9 & 34.1 & 8.17 & 2160 & 1796 & 264 & 4.02 \\
\hline Std. Err. & & \pm 0.3 & \pm 0.2 & \pm 0.03 & \pm 29 & \pm 24 & \pm 6 & \pm 0.09 \\
\hline Subtidal & Summer & 31.5 & 33.8 & 8.06 & 2194 & 1850 & 361 & 3.97 \\
\hline Std. Err. & & \pm 0.5 & \pm 0.1 & \pm 0.01 & \pm 13 & \pm 14 & \pm 4 & \pm 0.05 \\
\hline Subtidal & Winter & 24.8 & 34.1 & 8.11 & 2204 & 1882 & 323 & 3.56 \\
\hline Std. Err. & & \pm 0.4 & \pm 0.2 & \pm 0.02 & \pm 10 & \pm 17 & \pm 26 & \pm 0.19 \\
\hline \multicolumn{9}{|l|}{ Coral Bay } \\
\hline Coral Bay & Summer & 24.3 & 34.9 & 8.09 & 2286 & 1960 & 341 & 3.56 \\
\hline Std. Err. & & \pm 0.9 & \pm 0.1 & \pm 0.02 & \pm 9 & \pm 18 & \pm 12 & \pm 0.14 \\
\hline Coral Bay & Winter & 23.2 & 34.8 & 8.15 & 2263 & 1914 & 289 & 3.77 \\
\hline Std. Err. & & \pm 0.4 & \pm 0.0 & \pm 0.01 & \pm 8 & \pm 10 & \pm 9 & \pm 0.08 \\
\hline
\end{tabular}

'Std. Err.' represents \pm 1 standard error in averages shown. See Figs. 4, 5 for continuous temperature records from each region

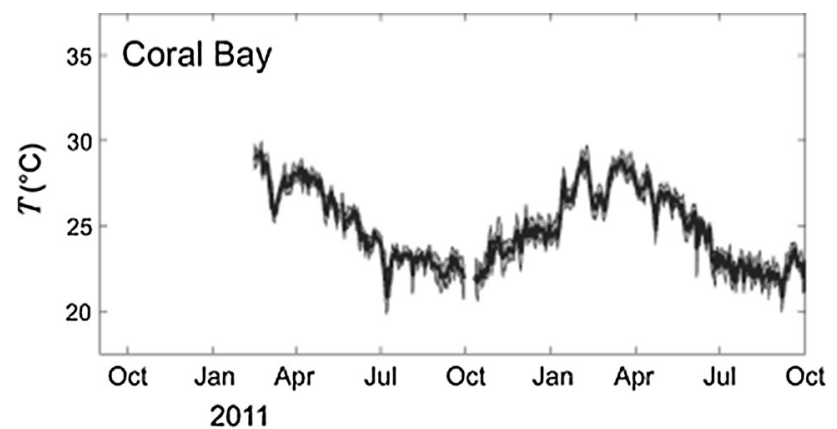

Fig. 5 Water column temperatures recorded at the Coral Bay site from February 2011 through October 2012. The heavy black line represents daily average temperatures, while the grey regions represent the range between hourly minimum and maximum temperatures for each day. Note that the scale of the $y$-axis is the same as in Fig. 4

atmospheric in both seasons: $289 \mu$ atm in summer and $351 \mu \mathrm{atm}$ in winter. Given the opposing effects of temperature and $\mathrm{pH}, \Omega_{\mathrm{ar}}$ values were not significantly different on average between summer and winter (3.6-3.7) (Fig. 6).

\section{Coral calcification}

The total bioactive surface area for all morphologies (branching, flabello-meandroid, and massive) was significantly and positively correlated with fragment mass $\left(r^{2}=0.58-0.96, p<0.01\right.$; Fig. 7; Electronic Supplementary Materials, ESM, Table S1). Calcification in A. aspera at Cygnet Bay was significantly affected by both the degree of tidal exposure and individual season even though seasonal patterns in coral growth rates were mixed across sites (Table 2; Fig. 8). Nonetheless, on an annual basis, $A$. aspera at the isolated site calcified at rates that were $\sim 30 \%$ lower than at either the subtidal or intermediate sites $(0.40 \pm 0.03$ vs. $0.58 \pm 0.03$ and $0.59 \pm 0.02 \mathrm{~g}$ $\left.\mathrm{cm}^{-2} \mathrm{yr}^{-1}\right)$, mainly as a result of slower calcification in summer $\left(0.73 \pm 0.08 \mathrm{mg} \mathrm{cm}^{-2} \mathrm{~d}^{-1}\right.$ vs. $1.34 \pm 0.04$, and $1.59 \pm 0.08 \mathrm{mg} \mathrm{cm}^{-2} \mathrm{~d}^{-1}$ in winter). Unlike A. aspera, calcification in $D$. favus was not significantly influenced by season at either Cygnet Bay or Coral Bay (Tables 2, 3; Fig. 8); however, it was influenced by the intertidal location at Cygnet Bay (Table 2). In further contrast with $A$. aspera, calcification in $D$. favus was fastest at the most tidally exposed site: $0.40 \pm 0.03 \mathrm{~g} \mathrm{~cm}^{-2} \mathrm{yr}^{-1}(1.10 \pm$ $0.07 \mathrm{mg} \mathrm{cm}^{-2} \mathrm{~d}^{-1}$ ) or $\sim 30 \%$ faster than rates at the intermediate and subtidal sites $(0.30 \pm 0.02$ and $0.29 \pm$ $0.02 \mathrm{~g} \mathrm{~cm}^{-2} \mathrm{yr}^{-1}$, respectively). For $T$. geoffroyi, both season and tidal exposure influenced calcification rates (Table 2; ESM Table S2); however, the 'seasonal' effect was manifest mainly as a significant overall downward trend in calcification rates at all sites in Cygnet Bay (Fig. 8). For instance, there was no apparent seasonal dependency when comparing summer rates to average winter rates $\left(0.33 \pm 0.04\right.$ and $\left.0.35 \pm 0.04 \mathrm{mg} \mathrm{cm}^{-2} \mathrm{~d}^{-1}\right)$. Similar to D. favus, calcification in $T$. geoffroyi was $\sim 30 \%$ faster at the tidally exposed sites $(0.16 \pm 0.02$ and $0.15 \pm 0.01 \mathrm{~g} \mathrm{~cm}^{-2} \mathrm{yr}^{-1}$ at the isolated and intermediate sites, respectively) than at the subtidal site $(0.12 \pm$ $0.01 \mathrm{~g} \mathrm{~cm}^{-2} \mathrm{yr}^{-1}$ ).

The influence of both region and individual season was significant when comparing rates of calcification in $A$. 
Fig. 6 Diurnal variations in temperature in the intermediate pool (green line) and offshore water levels (blue line) over a spring tide during field trips in a autumn and b spring. Diurnal variations in downwelling light reaching the benthos of the intermediate pool (red line) and offshore water levels (blue line) over a spring tide during the same field trips in c autumn and d spring
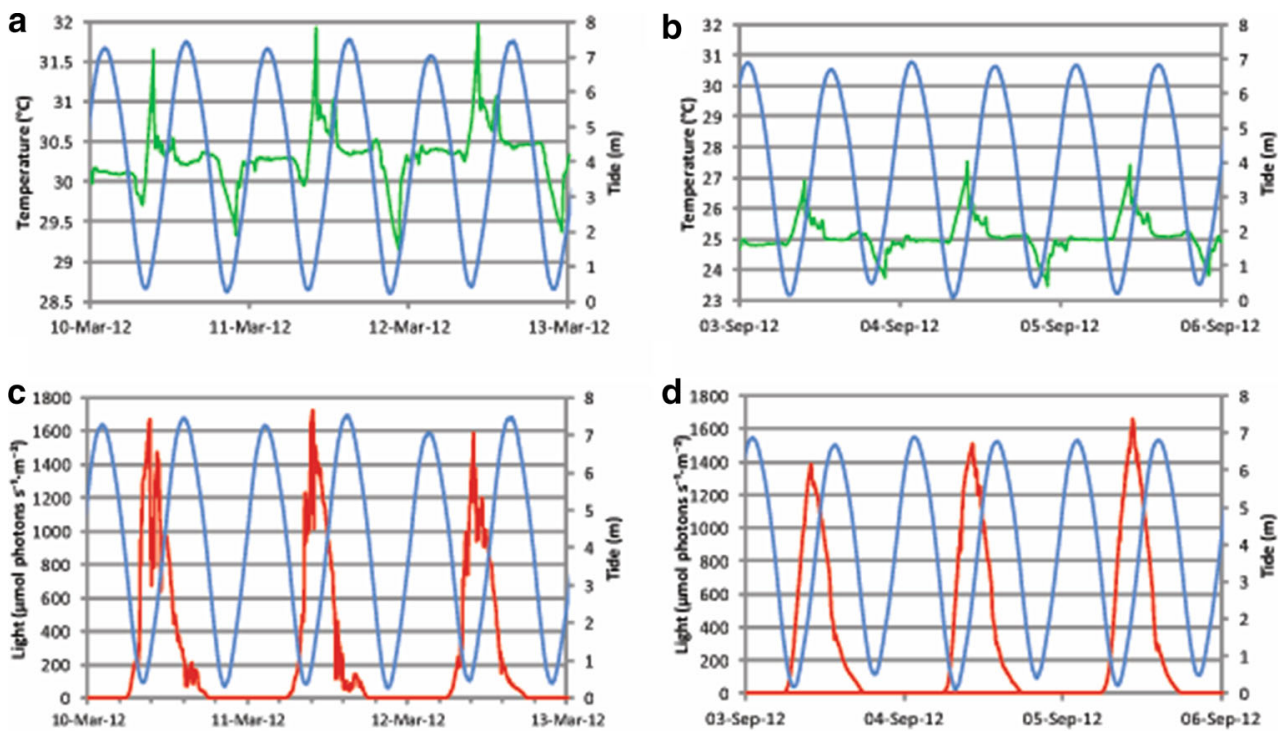

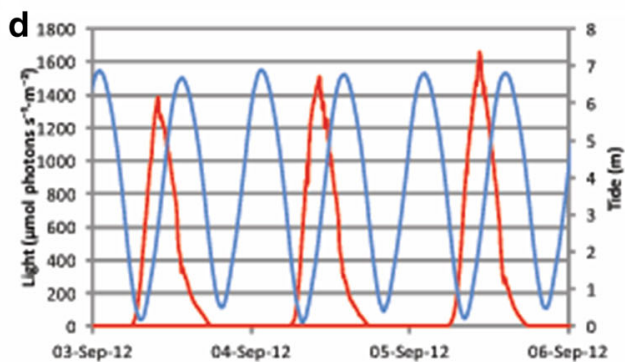

aspera at Cygnet Bay to A. muricata at Coral Bay as well as between $D$. favus at both sites (Table 3; ESM Table S3). Calcification in A. muricata at Coral Bay was $14 \%$ faster in the winter than summer $(\Delta$ calc. $=0.12 \pm 0.07$ $\mathrm{mg} \mathrm{cm} \mathrm{cm}^{-2} \mathrm{~d}^{-1}$, but still $42 \%$ slower than in A. aspera at the subtidal site of Cygnet Bay $(0.34 \pm 0.02$ vs. $\left.0.59 \pm 0.02 \mathrm{~g} \mathrm{~cm}^{-2} \mathrm{yr}^{-1}\right)$. Calcification in D. favus at Coral Bay was also $24 \%$ faster in winter than summer ( $\Delta$ calc. $=0.26 \pm 0.07 \mathrm{mg} \mathrm{cm}^{-2} \mathrm{~d}^{-1}$ ) and $52 \%$ faster than in D. favus at the subtidal site of Cygnet Bay $\left(0.44 \pm 0.03\right.$ vs. $\left.0.29 \pm 0.02 \mathrm{~g} \mathrm{~cm}^{-2} \mathrm{yr}^{-1}\right)$. Calcification rates in L. hemprichii at Coral Bay increased steadily over the course of the study from $0.45 \pm 0.04$ to $0.78 \pm$ $0.06 \mathrm{mg} \mathrm{cm}^{-2} \mathrm{~d}^{-1}$ or at an average annual calcification rate of $0.23 \pm 0.02 \mathrm{~g} \mathrm{~cm}^{-2} \mathrm{yr}^{-1}$ (Fig. 8). Looking across all sites and both regions, we found that Acropora spp. generally calcified the fastest $(0.34 \pm 0.02$ to $0.59 \pm$ $\left.0.02 \mathrm{~g} \mathrm{~cm}^{-2} \mathrm{yr}^{-1}\right)$, followed by $D$. favus $(0.29 \pm 0.02$ to $\left.0.44 \pm 0.03 \mathrm{~g} \mathrm{~cm}^{-2} \mathrm{yr}^{-1}\right), \quad$ L. hemprichii $(0.23 \pm 0.02$ $\left.\mathrm{g} \mathrm{cm}^{-2} \mathrm{yr}^{-1}\right)$, and $T$. geoffroyi $(0.12 \pm 0.01$ to $0.16 \pm$ $\left.0.02 \mathrm{~g} \mathrm{~cm}^{-2} \mathrm{yr}^{-1}\right)$.

\section{Discussion}

Nearshore waters in the Kimberley provide some of the warmest and most variable habitats where scleractinian corals are abundant (Veron 2000). The large diurnal tidal range in the Kimberley region (8-12 m) causes fairly expansive intertidal habitat subject to highly variable water temperatures, ranging up to $\sim 7{ }^{\circ} \mathrm{C}$ over a single diel cycle. This makes the nearshore intertidal of Cygnet Bay comparable to other high and variable temperature environments where scleractinian coral is abundantly found, such as backreef habitats in American Samoa (Craig et al. 2001; Oliver and Palumbi 2009) and outer reef environments of the Red Sea, albeit not quite as extreme as in the Persian Gulf (Riegl et al. 2011; Bauman et al. 2013) or nearshore environments of the Red Sea (Pineda et al. 2013). Furthermore, the temperature of coral tissue within the shallower and more isolated pools in Cygnet Bay $(\leq 0.2 \mathrm{~m}$ deep) could be reaching in situ temperatures of up to $\sim 36{ }^{\circ} \mathrm{C}$ at midday in summer due to the stagnant water motion being limited to flows on the order of $\sim 1 \mathrm{~cm} \mathrm{~s}^{-1}$ or less at low tide (Fabricius 2006; Jimenez et al. 2008). At the same time, both daytime elevations and night-time depressions in water temperature within the intertidal will generally last just $2-4 \mathrm{~h}$ before these environments are renewed by rising tides and temperatures return to offshore levels, thus providing some respite to transient thermal stress (Mayfield et al. 2013).

The current conventional model of temperature-dependent coral growth indicates that once coral have exceeded their thermal growth optimum, rates of calcification will decline with increasing temperature (Jokiel and Coles 1977; Marshall and Clode 2004). Coral calcification, however, responds differently to increases in temperature across regions than it does to increases in temperature from within the same habitat. For example, prior studies have found that massive Porites living in high-temperature environments with annual sea surface temperatures greater than $29{ }^{\circ} \mathrm{C}$ calcify at rates that are comparable to or faster than those living in more average tropical waters of $\sim 25{ }^{\circ} \mathrm{C}$ (Smith et al. 2007; Lough and Cantin 2014). In other cases, there may be no clear optimal temperature for a given reef habitat (e.g., Putnam and Edmunds 2011).

We found that corals within the globally important reefbuilding genera Acropora also calcified at comparable rates 

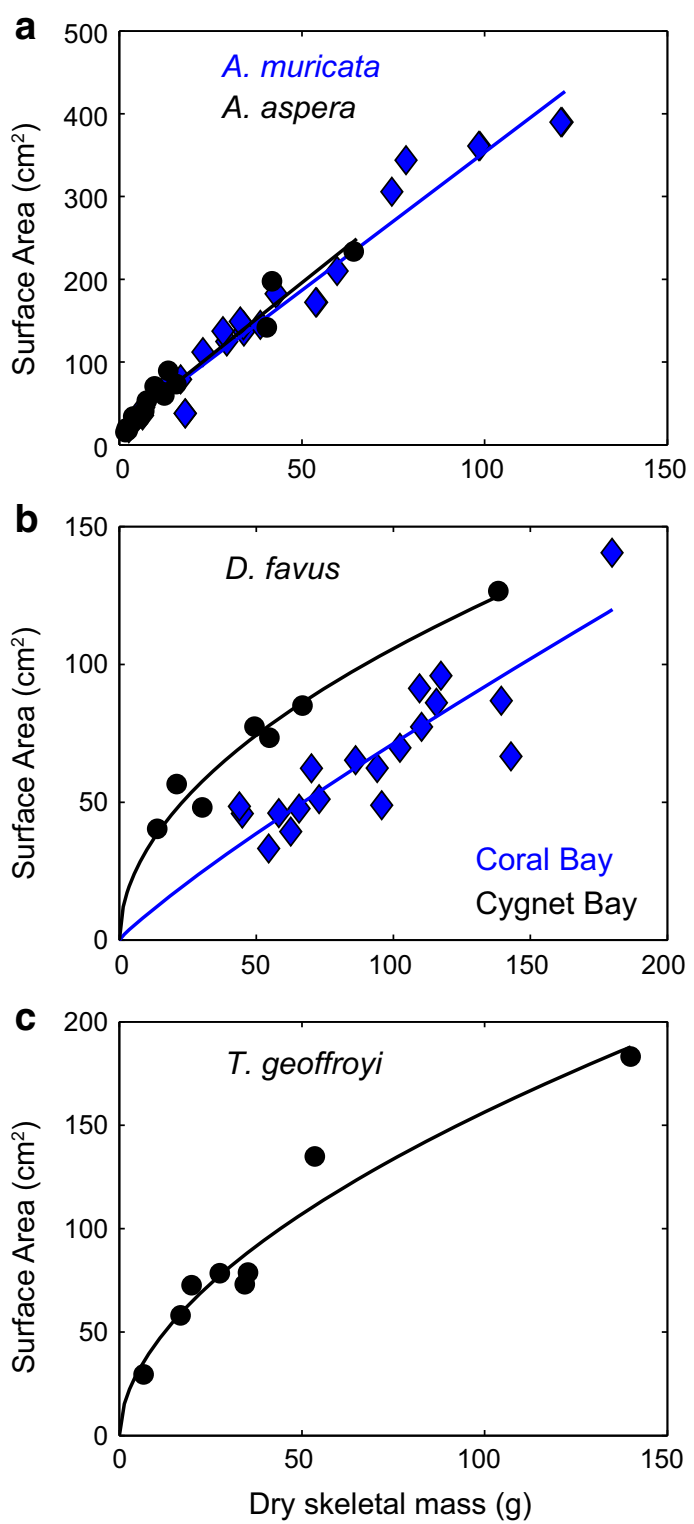

Fig. 7 Relationships between measured surface area and skeletal mass of Acropora aspera and Acropora muricata (a), Dipsastraea favus (b), and Trachyphyllia geoffoyi (c) fragments from Coral Bay (blue diamonds) and Cygnet Bay (black circles). The solid lines represent best-fit linear regressions for A. aspera and A. muricata and nonlinear regressions of the type $y=A x^{\mathrm{b}}$ for all other coral species. The numerical results for each regression shown are given in ESM Table S1

across different thermal habitats, albeit with some nuances. On an annual basis, $A$. aspera in the most tidally isolated site in Cygnet Bay calcified at rates similar to A. muricata living in Coral Bay; however, there was a significant and substantial depression (50\%) in summer calcification rates relative to winter at the isolated site that was not observed elsewhere. This inverse seasonal behaviour in calcification (higher in winter than summer) was partially mirrored by A. muricata in Coral Bay, albeit to a lesser extent
Table 2 Mixed effects model analysis testing the influence of the season and degree of tidal exposure at Cygnet Bay on the coral calcification rates in Acropora aspera, Dipsastraea favus, and Trachyphyllia geoffroyi using growth in the subtidal as a reference for site and in the second winter as a reference for season

\begin{tabular}{|c|c|c|c|c|}
\hline Factor & Group & $\begin{array}{l}\Delta \text { calcif. } \\
\left(\mathrm{mg} \mathrm{cm}^{-2} \mathrm{~d}^{-1}\right)\end{array}$ & $d f$ & $p$ \\
\hline \multicolumn{5}{|c|}{ A. aspera } \\
\hline \multirow[t]{3}{*}{ Site } & Isolated & -0.38 & 34.27 & $<0.01$ \\
\hline & Intermediate & -0.06 & 31.15 & 0.51 \\
\hline & Subtidal & 0 & - & - \\
\hline \multirow[t]{3}{*}{ Season } & Winter 1 & 0.18 & 77.92 & 0.04 \\
\hline & Summer & -0.10 & 77.94 & 0.26 \\
\hline & Winter 2 & 0 & - & - \\
\hline \multicolumn{5}{|c|}{ D. favus } \\
\hline \multirow[t]{3}{*}{ Site } & Isolated & 0.34 & 24.54 & $<0.01$ \\
\hline & Intermediate & 0.03 & 25.83 & 0.71 \\
\hline & Subtidal & 0 & - & - \\
\hline \multirow[t]{3}{*}{ Season } & Winter 1 & 0.02 & 53.20 & 0.72 \\
\hline & Summer & 0.06 & 52.54 & 0.32 \\
\hline & Winter 2 & 0 & - & - \\
\hline \multicolumn{5}{|c|}{ T. geoffroyi } \\
\hline \multirow[t]{3}{*}{ Site } & Isolated & 0.12 & 26.08 & 0.01 \\
\hline & Intermediate & 0.08 & 24.45 & 0.07 \\
\hline & Subtidal & 0 & - & - \\
\hline \multirow[t]{3}{*}{ Season } & Winter 1 & 0.29 & 51.17 & $<0.01$ \\
\hline & Summer & 0.08 & 49.45 & 0.01 \\
\hline & Winter 2 & 0 & - & - \\
\hline
\end{tabular}

' $d f$ ' is the calculated degrees of freedom for each cross-group comparison (e.g., isolated and subtidal), and ' $p$ ' represents the computed level of significance

$(\Delta$ calc. $=-13 \% ; p=0.108, d f=21.26)$. A separate but contemporary study of Acropora pulchra at Coral Bay also showed marginal differences between winter and summer calcification rates $(<15 \%$ in 2011-2013), possibly due to the cumulative stress of two anomalously warm summers following an initially strong marine heat wave in 2011 (Depczynski et al. 2013; Foster et al. 2014). However, earlier measurements of net calcification in an Acroporadominated Ningaloo Reef community also showed minimal differences between winter and summer several years before the 2011 heat wave, possibly due to increased rates of particle feeding in winter (Falter et al. 2012; Wyatt et al. 2012). Thus, the absence of a well-defined seasonality in calcification rates for Acropora spp. from Ningaloo Reef may not be due to extreme summer temperatures. The significant and substantial absence of a seasonal response of A. aspera calcification to the highly variable and elevated summer temperatures in the most tidally isolated pool at Cygnet Bay is more suggestive of a temperaturedriven response. Thus, summer conditions within the high 


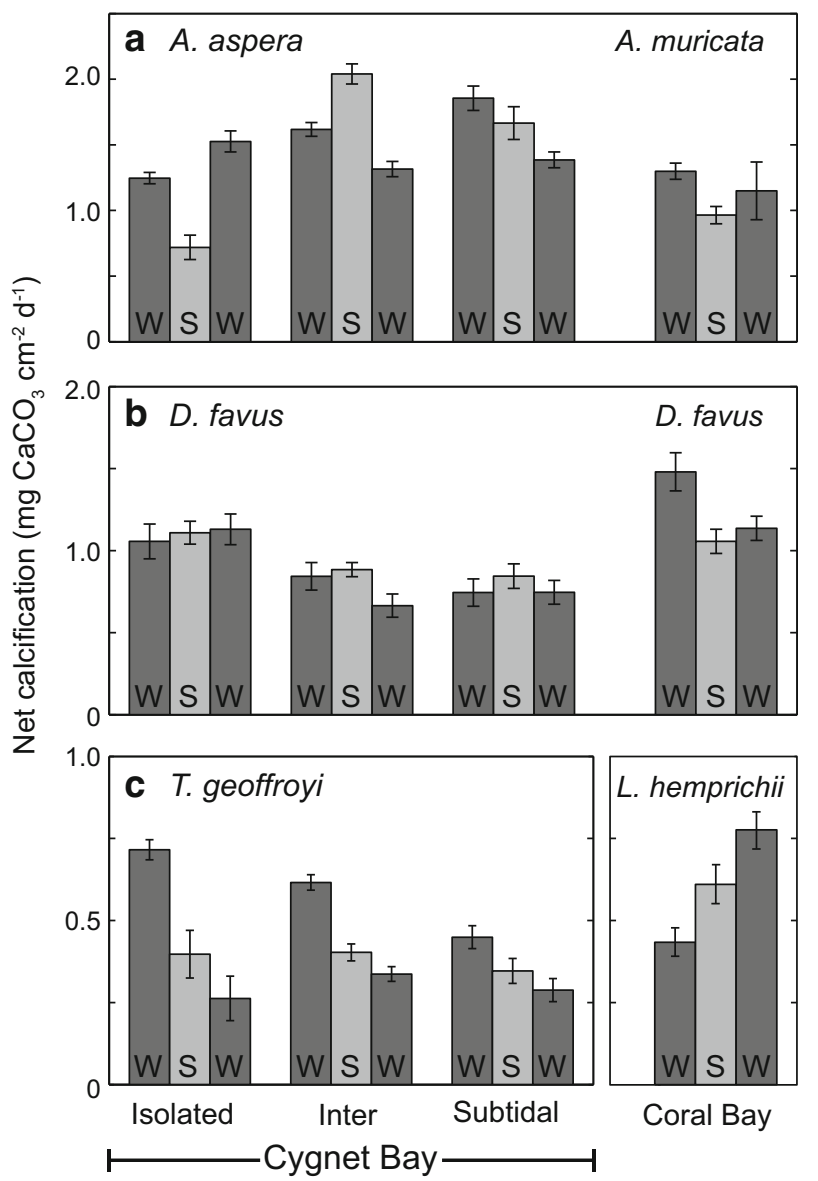

Fig. 8 Average net calcification rates $( \pm \mathrm{SE})$ for specimens of Acropora aspera and Acropora muricata (a), Dipsastraea favus (b), Trachyphyllia geoffroyi (c), and Lobophyllia hemprichii (bottom) over summer (September to March) and winter (March or April to September) at sites at Cygnet Bay in the Kimberley Region and at Coral Bay along Ningaloo Reef from April 2011 to September 2012 intertidal zone of the Kimberley may be approaching the upper limit of habitat suitability for Acropora spp.

In contrast to A. aspera, summer conditions within the high intertidal zone did not greatly slow the growth of $D$. favus or T. geoffroyi; in fact, both species calcified $\sim 30 \%$ faster in the intertidal than in the subtidal (Fig. 8). More importantly, D. favus from the most isolated intertidal site calcified at rates not significantly different from those measured in Coral Bay, even over summer when temperatures exceeded $31^{\circ} \mathrm{C}$ on average for over a month. The consistent overall decline in $T$. geoffroyi calcification across all Cygnet Bay sites was most likely the result of its particular morphology, developmental strategy, and life history. Trachyphyllia geoffroyi is often classified as a noncolonial coral (Veron 2000), and most of the colonies we found at Cygnet Bay had only 3-6 mouth openings over an area of $60-80 \mathrm{~cm}^{2}$, equivalent to $15-20 \mathrm{~cm}^{2}$ per mouth, whereas the largest colonies had 19 mouth openings over an area of $\sim 180 \mathrm{~cm}^{2}$, equivalent to $\sim 9 \mathrm{~cm}^{2}$ per mouth. It would thus seem that as $T$. geoffroyi colonies age, the division of the colony continues even as the overall rate of growth slows down.

Our results, in conjunction with what has been reported recently in the literature (Smith et al. 2007), indicate that there are scleractinian coral species living in high and variable temperature environments which can calcify at rates that are comparable to or faster than similar species growing in lower and less variable temperature environments. The response of individual coral species across different levels of tidal exposure within the same reef location $(<1 \mathrm{~km}$ or less) is unlikely to stem from differences in genotype due to the high level of hydrodynamic connectivity with adjacent coastal waters. Thus, differ-
Table 3 Mixed effects model analysis testing the influence of the season and region on calcification rates in Acropora aspera and Acropora muricata as well as Dipsastraea favus using growth in the subtidal zone of Cygnet Bay as a reference for region and in the second winter as a reference for season

\begin{tabular}{llcll}
\hline Factor & Group & $\Delta$ calcif. $\left(\mathrm{mg} \mathrm{cm}^{-2} \mathrm{~d}^{-1}\right)$ & $d f$ & $p$ \\
\hline Acropora spp. & & & & \\
Region & Coral Bay & -0.64 & 62 & $<0.01$ \\
& Cygnet Bay & 0 & - & - \\
Season & Winter 1 & 0.14 & 62 & 0.14 \\
& Summer & -0.05 & 62 & 0.59 \\
& Winter 2 & 0 & - & - \\
D. favus & & & & $<0.01$ \\
Region & Coral Bay & 0.53 & 27.19 & - \\
& Cygnet Bay & 0 & - & $<0.01$ \\
Season & Winter 1 & 0.33 & 55.44 & 0.74 \\
& Summer & -0.03 & 55.44 & - \\
\hline
\end{tabular}

' $d f$ ' is the calculated degrees of freedom for each cross-group comparison (e.g., Coral Bay and Cygnet Bay), and ' $p$ ' represents the computed level of significance 
ences in the growth rates of the same species of coral across different habitats within Cygnet Bay are likely to depend on the a priori 'frontloading' of genes involved in heat resistance within the coral host, and/or the ability for corals to adjust their physiology in accordance with shortterm changes $(\sim$ weeks $)$ in environmental conditions (Barshis et al. 2013; Palumbi et al. 2014). It is still possible, however, that such physiological adjustments (e.g., through higher rates of heat shock protein production and/or superoxide scavenging) could exert energetic costs high enough to subvert rates of calcification, thus partly explaining the lower calcification rates by A. aspera in summer and in the most isolated intertidal site at Cygnet Bay (Table 2). Regional differences in how coral growth responds to changing environmental conditions can also be influenced by differences in symbiont clade (Baker et al. 2004; Oliver and Palumbi 2009; Stat and Gates 2011; Sawall et al. 2014; Hume et al. 2015); however, recent studies have shown that less than $10 \%$ of Acropora species living in the Kimberley host symbionts of a clade other than C (Thomas et al. 2014). This suggests that the genetic diversity has to originate from adaption within the existing clades to buffer them against changes in their thermal climate. Future studies aimed at understanding how coral at Cygnet Bay is able to maintain such robust rates of calcification despite the high and variable water temperatures would be well served to consider their respective genetic composition and physiology, as well as examine both variations in calcification rates over longer time scales (e.g., inter-annual). To the best of our knowledge, there still have been no reports of regional-scale mass bleaching in the Kimberley; thus, the Kimberley region provides an excellent natural laboratory in which to study the ability of scleractinian coral to grow and survive in high and variable temperature environments.

\begin{abstract}
Acknowledgments This study was made possible by funding provided through the ARC Centre of Excellence in Coral Reef Studies, a Ph.D. SIRF Scholarship awarded to Sana Dandan, a Premiers Fellowship and ARC Laureate awarded to Malcolm McCulloch, an ARC Future Fellowship awarded to Ryan Lowe, together with funding provided by the Western Australian Marine Science Institution as part of the Kimberley Marine Research Node which operates through research collaboration with Traditional Owner groups particularly the Badi Jawi people at One Arm Point including other stakeholders throughout the region. We would also like to thank the Kimberley Marine Research Station, Cygnet Bay Pearls and Ali McCarthy in particular. We also thank Frazer McGregor at Murdoch University field station at Coral Bay for field work support as well as Taryn Foster, Jessie Short, Leo Ruiz-Montoya, Lucy Georgiou, and Napo Cayabyab for additional help with field work.
\end{abstract}

Open Access This article is distributed under the terms of the Creative Commons Attribution 4.0 International License (http://crea tivecommons.org/licenses/by/4.0/), which permits unrestricted use, distribution, and reproduction in any medium, provided you give appropriate credit to the original author(s) and the source, provide a link to the Creative Commons license, and indicate if changes were made.

\section{References}

Anthony K, Kerswell A (2007) Coral mortality following extreme low tides and high solar radiation. Mar Biol 151:1623-1631

Anthony KRN, Connolly SR, Hoegh-Guldberg O (2007) Bleaching, energetics, and coral mortality risk: Effects of temperature, light, and sediment regime. Limnol Oceanogr 52:716-726

Bak R (1973) Coral weight increment in situ. A new method to determine coral growth. Mar Biol 20:45-49

Bak RPM, Meesters EH (1998) Coral population structure: the hidden information of colony size-frequency distributions. Mar Ecol Prog Ser 162:301-306

Baker AC, Starger CJ, McClanahan TR, Glynn PW (2004) Corals' adaptive response to climate change. Nature 430:741

Barshis DJ, Ladner JT, Oliver TA, Seneca FO, Traylor-Knowles N, Palumbi SR (2013) Genomic basis for coral resilience to climate change. Proc Natl Acad Sci USA 110:1387-1392

Bauman AG, Baird AH, Cavalcante GH (2011) Coral reproduction in the world's warmest reefs: southern Persian Gulf (Dubai, United Arab Emirates). Coral Reefs 30:405-413

Bauman AG, Feary DA, Heron SF, Pratchett MS, Burt JA (2013) Multiple environmental factors influence the spatial distribution and structure of reef communities in the northeastern Arabian Peninsula. Mar Pollut Bull 72:302-312

Bucher DJ, Harriott VJ, Roberts LG (1998) Skeletal micro-density, porosity and bulk density of acroporid corals. J Exp Mar Biol Ecol 228:117-136

Budd AF, Fukami H, Smith ND, Knowlton N (2012) Taxonomic classification of the reef coral family Mussidae (Cnidaria: Anthozoa: Scleractinia). Zool J Linn Soc 166:465-529

Burton E, Walter L (1987) Relative precipitation rates of aragonite and $\mathrm{Mg}$ calcite from seawater: Temperature or carbonate ion control? Geology 15:111-114

Cantin NE, Cohen AL, Karnauskas KB, Tarrant AM, McCorkle DC (2010) Ocean warming slows coral growth in the central Red Sea. Science 329:322-325

Carilli J, Donner SD, Hartmann AC (2012) Historical temperature variability affects coral response to heat stress. PLoS One 7:e34418

Castillo KD, Ries JB, Weiss JM, Lima FP (2012) Decline of forereef corals in response to recent warming linked to history of thermal exposure. Nat Clim Chang 2:756-760

Cooper TF, O'Leary RA, Lough JM (2012) Growth of Western Australian Corals in the Anthropocene. Science 335:593-596

Cooper TF, Ulstrup KE, Dandan SS, Heyward AJ, Kühl M, Muirhead A, O'Leary RA, Ziersen BEF, Van Oppen MJH (2010) Niche specialization of reef-building corals in the mesophotic zone: metabolic trade-offs between divergent Symbiodinium types. Proc R Soc Lond B Biol Sci 278:1840-1850

Craig P, Birkeland C, Belliveau S (2001) High temperatures tolerated by a diverse assemblage of shallow-water corals in American Samoa. Coral Reefs 20:185-189

De'ath G, Lough JM, Fabricius KE (2009) Declining Coral Calcification on the Great Barrier Reef. Science 323:116-119

Depczynski M, Gilmour JP, Ridgway T, Barnes H, Heyward AJ, Holmes TH, Moore JAY, Radford BT, Thomson DP, Tinkler P, Wilson SK (2013) Bleaching, coral mortality and subsequent survivorship on a West Australian fringing reef. Coral Reefs $32: 233-238$ 
Donner S, Heron S, Skirving W (2009) Future scenarios: a review of modelling efforts to predict the future of coral reefs in an era of climate change. In: Oppen MH, Lough J (eds) Coral bleaching. Springer, Heidelberg, pp 159-173

D'Olivo JP, McCulloch MT, Judd K (2013) Long-term records of coral calcification across the central Great Barrier Reef: assessing the impacts of river runoff and climate change. Coral Reefs 32:999-1012

Fabricius KE (2006) Effects of irradiance, flow, and colony pigmentation on the temperature microenvironment around corals: Implications for coral bleaching? Limnol Oceanogr 51:30-37

Falter JL, Lowe RJ, Atkinson MJ, Cuet P (2012) Seasonal coupling and de-coupling of net calcification rates from coral reef metabolism and carbonate chemistry at Ningaloo Reef, Western Australia. J Geophys Res Oceans 117:C05003

Falter JL, Zhang Z, Lowe RJ, McGregor F, Keesing J, McCulloch MT (2014) Assessing the drivers of spatial variation in thermal forcing across a nearshore reef system and implications for coral bleaching. Limnol Oceanogr 59:1241-1255

Frieler K, Meinshausen M, Mengel M, Braun N, Hare W (2012) A scaling approach to probabilistic assessment of regional climate change. J Clim 25:3117-3144

Foster T, Short JA, Falter JL, Ross C, McCulloch MT (2014) Reduced calcification in Western Australian corals during anomalously high summer water temperatures. J Exp Mar Bio Ecol 461:133-143

Furby K, Bouwmeester J, Berumen M (2013) Susceptibility of central Red Sea corals during a major bleaching event. Coral Reefs 32:505-513

Gilmour JP, Smith LD, Heyward AJ, Baird AH, Pratchett MS (2013) Recovery of an isolated coral reef system following severe disturbance. Science 340:69-71

Hoegh-Guldberg O (1999) Climate change, coral bleaching and the future of the world's coral reefs. Mar Freshw Res 50:839-866

Hoegh-Guldberg O, Mumby PJ, Hooten AJ, Steneck RS, Greenfield P, Gomez E, Harvell CD, Sale PF, Edwards AJ, Caldeira K, Knowlton N, Eakin CM, Iglesias-Prieto R, Muthiga N, Bradbury RH, Dubi A, Hatziolos ME (2007) Coral reefs under rapid climate change and ocean acidification. Science 318:1737-1742

Howells EJ, Beltran VH, Larsen NW, Bay LK, Willis BL, van Oppen MJH (2011) Coral thermal tolerance shaped by local adaptation of photosymbionts. Nat Clim Chang 2:116-120

Hume BCC, D'Angelo C, Smith EG, Stevens JR, Burt J, Wiedenmann J (2015) Symbiodinium thermophilum sp. nov., a thermotolerant symbiotic alga prevalent in corals of the world's hottest sea, the Persian/Arabian Gulf. Sci Rep 5:8562

Jimenez IM, Kuhl M, Larkum AWD, Ralph PJ (2008) Heat budget and thermal microenvironment of shallow-water corals: Do massive corals get warmer than branching corals? Limnol Oceanogr 53:1548-1561

Jokiel PL, Coles SL (1977) Effects of temperature on the mortality and growth of Hawaiian reef corals. Mar Biol 43:201-208

Jokiel PL, Maragos JE, Franzisket L (1978) Coral growth: buoyant weight technique. In: Stoddart DR, Johannes RE (eds) Coral reef: research methods, vol 78. UNESCO, Paris, pp 379-396

Kowalik Z (2004) Tide distribution and tapping into tidal energy. Oecologia 46:291-331

Lesser MP, Farrell JH (2004) Exposure to solar radiation increases damage to both host tissues and algal symbionts of corals during thermal stress. Coral Reefs 23:367-377

Lewis E, Wallace DWR (1998) Program Developed for $\mathrm{CO}_{2}$ System Calculations. In: Center CDIA (ed). Oak Ridge National Laboratory, U.S. Department of Energy

Lough JM, Cantin NE (2014) Perspectives on Massive Coral Growth Rates in a Changing Ocean. Biol Bull 226:187-202
Lowe RJ, Leon AS, Symonds G, Falter JL, Gruber R (2015) The intertidal hydraulics of tide-dominated reef platforms. J Geophys Res Oceans. doi:10.1002/2015JC010701

Manzello DP, Enochs IC, Bruckner A, Renaud PG, Kolodziej G (2014) Galápagos coral reef persistence after ENSO warming across an acidification gradient. Geophys Res Lett 41:9001-9008

Marsh JA (1970) Primary Productivity of Reef-Building Calcareous Red Algae. Ecology 51:255-263

Marshall AT, Clode P (2004) Calcification rate and the effect of temperature in a zooxanthellate and an azooxanthellate scleractinian reef coral. Coral Reefs 23:218-224

Mass T, Genin A, Shavit U, Grinstein M, Tchernov D (2010) Flow enhances photosynthesis in marine benthic autotrophs by increasing the efflux of oxygen from the organism to the water. Proc Natl Acad Sci USA 107:2527-2531

Mayfield AB, Chen MN, Meng PJ, Lin HJ, Chen CS, Liu PJ (2013) The physiological response of the reef coral Pocillopora damicornis to elevated temperature: results from coral reef mesocosm experiments in Southern Taiwan. Mar Environ Res 86:1-11

McCulloch M, Falter J, Trotter J, Montagna P (2012) Coral resilience to ocean acidification and global warming through $\mathrm{pH}$ upregulation. Nat Clim Chang 2:623-633

Moore JAY, Bellchambers LM, Depczynski MR, Evans RD, Evans SN, Field SN, Friedman KJ, Gilmour JP, Holmes TH, Middlebrook R, Radford BT, Ridgway T, Shedrawi G, Taylor H, Thomson DP, Wilson SK (2012) Unprecedented mass bleaching and loss of coral across $12^{\circ}$ of latitude in Western Australia in 2010-11. PLoS One 7:e51807

Naumann MS, Niggl W, Laforsch C, Glaser C, Wild C (2009) Coral surface area quantification - evaluation of established techniques by comparison with computer tomography. Coral Reefs 28:109-117

Oliver TA, Palumbi SR (2009) Distributions of stress-resistant coral symbionts match environmental patterns at local but not regional scales. Mar Ecol Prog Ser 378:93-103

Oliver T, Palumbi S (2011) Do fluctuating temperature environments elevate coral thermal tolerance? Coral Reefs 30:429-440

Palumbi SR, Barshis DJ, Traylor-Knowles N, Bay RA (2014) Mechanisms of reef coral resistance to future climate change. Science 344:895-898

Pineda J, Starczak V, Tarrant A, Blythe J, Davis K, Farrar T, Berumen M, da Silva JCB (2013) Two spatial scales in a bleaching event: Corals from the mildest and the most extreme thermal environments escape mortality. Limnol Oceanogr 58:1531-1545

Piniak GA, Brown EK (2009) Temporal variability in chlorophyll fluorescence of back-reef corals in Ofu, American Samoa. Biol Bull 216:55-67

Putnam HM, Edmunds PJ (2011) The physiological response of reef corals to diel fluctuations in seawater temperature. J Exp Mar Biol Ecol 396:216-223

Richards ZT, Garcia RA, Wallace CC, Rosser NL, Muir PR (2015) A diverse assemblage of reef corals thriving in a dynamic intertidal reef setting (Bonaparte Archipelago, Kimberley, Australia). PLoS One 10:e117791

Riegl B, Korrubel JL, Martin C (2001) Mapping and monitoring of coral communities and their spatial patterns using a surfacebased video method from a vessel. Bull Mar Sci 69:869-880

Riegl BM, Purkis SJ, Al-Cibahy AS, Abdel-Moati MA, HoeghGuldberg O (2011) Present limits to heat-adaptability in corals and population-level responses to climate extremes. PLoS One 6:e24802

Rosser N, Veron J (2011) Australian corals thriving out of water in an extreme environment. Coral Reefs 30:21

Sawall Y, Al-sofyani A, Banguera-Hinestroza E, Voolstra C (2014) Spatio-temporal analyses of Symbiodinium physiology of the 
coral Pocillopora verrucosa along large-scale nutrient and temperature gradients in the Red Sea. PLoS One 9:e103179

Sheppard C, Al-Husiani M, Al-Jamali F, Al-Yamani F, Baldwin R, Bishop J, Benzoni F, Dutrieux E, Dulvy NK, Durvasula SRV, Jones DA, Loughland R, Medio D, Nithyanandan M, Pilling GM, Polikarpov I, Price ARG, Purkis S, Riegl B, Saburova M, Samimi-Namin K, Taylor O, Wilson S, Zainal K (2010) The Gulf: A young sea in decline. Mar Pollut Bull 60:13-38

Smith LW, Barshis D, Birkeland C (2007) Phenotypic plasticity for skeletal growth, density and calcification of Porites lobata in response to habitat type. Coral Reefs 26:559-567

Stat M, Gates RD (2011) Clade D Symbiodinium in scleractinian corals: a nugget of hope, a selfish opportunist, an ominous sign, or all of the above? J Mar Biol 2011:730715

Thomas L, Kendrick GAW, Kennington WJ, Richards ZT, Stat M (2014) Exploring Symbiodinium diversity and host specificity in Acropora corals from geographical extremes of Western Australia with 454 amplicon pyrosequencing. Mol Ecol 23:3113-3126

Venn AA, Tambutté E, Holcomb M, Laurent J, Allemand D, Tambutté S (2013) Impact of seawater acidification on $\mathrm{pH}$ at the tissue-skeleton interface and calcification in reef corals. Proc Natl Acad Sci USA 110:1634-1639
Veron JEN (2000) Corals of the world. Volumes 1-3, Australian Institute of Marine Science, Townsville, Queensland, $1382 \mathrm{pp}$

Wallace C (1999) Staghorn corals of the world: a revision of the genus Acropora. CSIRO publishing, Collingwood, Victoria p 419

Wilson B, Blake S (2011) Notes on the origins and biogeomorphology of Montgomery reef, Kimberley, Western Australia. J R Soc West Aust 94:107-119

Wyatt ASJ, Falter JL, Lowe RJ, Humphries S, Waite AM (2012) Oceanographic forcing of nutrient uptake and release over a fringing coral reef. Limnol Oceanogr 57:401-419

Yao W, Byrne R (1998) Simplified seawater alkalinity analysis: Use of linear array spectrometers. Deep Sea Res Part I Oceanogr Res Pap 45:1383-1392

Zhang Z, Falter JL, Lowe RJ, Ivey G (2012) The combined influence of hydrodynamic forcing and calcification on the spatial distribution of alkalinity in a coral reef system. J Geophys Res Oceans 117:1-18

Zhang Z, Falter JL, Lowe RJ, Ivey G, McCulloch M (2013) Atmospheric forcing intensifies the effects of regional ocean warming on reef-scale temperature anomalies during a coral bleaching event. J Geophys Res Oceans 118:4600-4616 